\title{
A Simple, Cost-Effective Method for Leaf Area Estimation
}

\author{
S. K. Pandey and Hema Singh \\ Ecosystems Analysis Laboratory, Department of Botany, Banaras Hindu University, Varanasi 221005, India \\ Correspondence should be addressed to S. K. Pandey, skpbhu2007@gmail.com
}

Received 13 July 2011; Revised 25 August 2011; Accepted 1 September 2011

Academic Editor: Kang Chong

Copyright ( $\odot 2011$ S. K. Pandey and H. Singh. This is an open access article distributed under the Creative Commons Attribution License, which permits unrestricted use, distribution, and reproduction in any medium, provided the original work is properly cited.

\begin{abstract}
Easy, accurate, inexpensive, and nondestructive methods to determine individual leaf area of plants are a useful tool in physiological and agronomic studies. This paper introduces a cost-effective alternative (called here millimeter graph paper method) for standard electronic leaf area meter, using a millimeter graph paper. Investigations were carried out during August-October, 2009-2010, on 33 species, in the Botanical garden of the Banaras Hindu University at Varanasi, India. Estimates of leaf area were obtained by the equation, leaf area $\left(\mathrm{cm}^{2}\right)=x / y$, where $x$ is the weight $(\mathrm{g})$ of the area covered by the leaf outline on a millimeter graph paper, and $y$ is the weight of one $\mathrm{cm}^{2}$ of the same graph paper. These estimates were then compared with destructive measurements obtained through a leaf area meter; the two sets of estimates were significantly and linearly related with each other, and hence the millimeter graph paper method can be used for estimating leaf area in lieu of leaf area meter. The important characteristics of this cost-efficient technique are its easiness and suitability for precise, non-destructive estimates. This model can estimate accurately the leaf area of plants in many experiments without the use of any expensive instruments.
\end{abstract}

\section{Introduction}

Leaf area is an important variable for most ecophysiological studies in terrestrial ecosystems concerning light interception, evapotranspiration, photosynthetic efficiency, fertilizers, and irrigation response and plant growth (Blanco and Folegatti [1]). The easy, economic, and precise estimate of leaf surface area has been a concern to plant scientists for a long time. Plant physiologists require leaf area measurements for studying primary production in plants (Sestak et al. [2]; Tieszen [3]; Bleasdale [4]). Ecologists use leaf area relations for elucidating competition among different plant species (Harper [5]). Leaf area estimate is valuable in studies of plant nutrition, plant competition, plant-soil-water relations, plant protection measures, respiration, light reflectance, and heat transfer in plants (Mohsenin [6]), and thus it is an important parameter in understanding photosynthesis, light interception, water and nutrient use, and crop growth and yield potential (Smart [7]; Williams [8]). Leaf area estimation is often costly, time-consuming, and destructive (Marshall [9]). Sestak et al. [2] provided an extensive description of the most common methodology available till date that includes counting squares on millimeter graph paper, handplanimetry, the gravimetric method, dot counting, photoelectric planimetry, air-flow, linear measurements of leaves, leaf weighing, detached leaf counting, and the rating method. Well-known electronic meters can only be used if the plants have sparse and nonfragile leaves (Tieszen [3]; Bleadsdale [4]). A variety of computerized image analysis equipments and software are also available (Brodny et al. [10]). They measure quickly, accurately and nondestructively using a portable scanning planimeter (Daughtry [11]); however, the method is suitable only for small plants with few leaves (Nyakwende et al. [12]) and is expensive (Bignami and Rossini [13]). Several combinations of measurements and models relating length and width to area have been developed for several fruit trees, such as grape (Montero et al. [14]; Williams and Martinson [15]), avocado (Uzun and Celik [16]), pistachio (Ranjbar and Damme [17]), Cherry (H. Demirsoy and L. Demirsoy [18]), peach (Demirsoy et al. [19]), and Chestnut (Serdar and Demirsoy [20]). Some studies also use petiole length (Manivel and Weaver [21]) and leaf weight (Sepulveda and Kliewer [22]; Montero et al. [14]) for area measurement. The most common approach is 
to develop ratios and regression estimators by using easily measured leaf parameters such as length and width (Kvet and Marshall [23]). Lu et al. [24] proposed that the simple and linear relationships between leaf area and leaf dimensions (length, width) could be useful for nondestructive estimation of leaf area. Estimating leaf area from equations using leaf dimensions is an inexpensive, rapid, and nondestructive alternative for accurately assessing leaf area. Nondestructive models for leaf area determination have been established for many species such as maize (Stewart and Dwyer [25]), bean (Bhatt and Chanda [26]), taro (Lu et al. [24]), white clover (Gamper [27]), sugar beet (Tsialtas and Maslaris [28, 29]), sunflower (Kvet and Marshall [23], Rouphael et al. [30]), radish (Salerno et al. [31]), zucchini (Rouphael et al. [32]), strawberry (Demirsoy et al. [33]), grapevines (Manivel and Weaver [21]; Montero et al. [14], Williams and Martinson [15]), kiwi (Mendoza-de Gyves et al. [34]), chestnut (Serdar and Demirsoy [20]), hazelnut (Cristofori et al. [35]), eggplant (Rivera et al. [36]), faba bean (Peksen [37]), stevia (Ramesh et al. [38]), persimmon (Cristofori et al. [39]), medlar (Mendoza-de Gyves et al. [40]), small fruits (Fallovo et al. [41]), euphorbia (Fascella et al. [42]), saffron (Kumar [43]), ginger (Kandiannan et al. [44]), roses (Rouphael et al. [45]), and watermelon (Rouphael et al. [46]).

However, leaves may have complex shapes making leaf area determination using ratios of leaf parameters difficult, time consuming, and subject to larger errors. Therefore, the aim of this study was to develop an equation for leaf area estimate which is insensitive to changes in leaf shape, and is cost-effective. In this paper, a millimeter graph paper method is described, and its reliability is tested using an electronic leaf area meter.

\section{Materials and Methods}

Thirty-two (twelve- to thirty-five-year old) tree species and one (six-year old) shrub species growing at the Botanical garden of the Banaras Hindu University, Varanasi $\left(25^{\circ} 18^{\prime} \mathrm{N}\right.$ and $80^{\circ} 01^{\prime} \mathrm{E}$, at $126 \mathrm{~m}$ above sea level, mean annual rainfall $1100 \mathrm{~mm}$ ), were selected for the study. Leaves were sampled from different levels of the canopy, ten each from the thirty-three species, during the full-foliage period (AugustOctober) in 2009-2010. Each leaf was spread over millimeter graph paper, and the outline of leaf was drawn. The leaf area of each leaf was measured using a leaf area meter (SYSTRONICS, Leaf Area Meter-211) having a sensor and read-out unit. Using the paper knife, the area of the millimeter graph paper covered by the outline was cut and weighed on an electronic balance. One $\mathrm{cm}^{2}$ of the same millimeter graph paper was also cut and weighed. Leaves of some species were sampled more than once.

The following equation was used to calculate the leaf area nondestructively:

Leaf area $\left(\mathrm{cm}^{2}\right)=x / y$, where $x$ is the weight of the graph paper covered by the leaf outline (g) and $y$ is the weight $(\mathrm{g})$, of the $\mathrm{cm}^{2}$ area of the graph paper. In addition, areas of ten leaves each from five species were measured using the leaf area meter while still attached to the plants. Outline of these

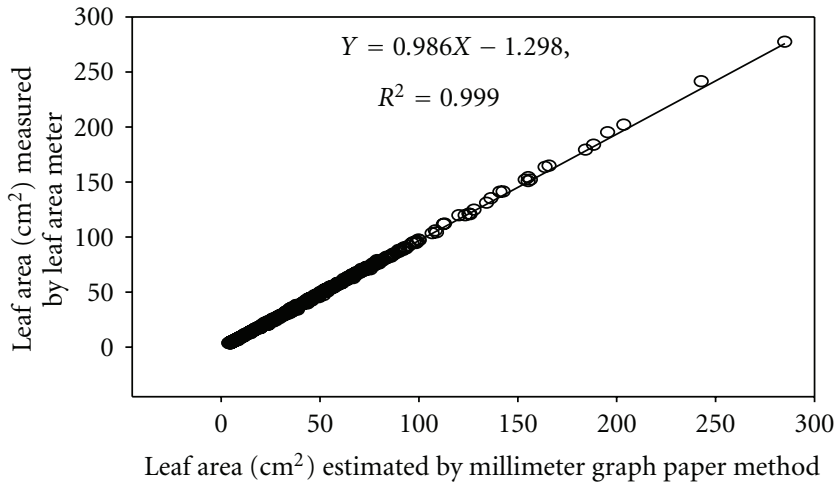

FIgURE 1: Relationship between leaf area of detached leaves measured by leaf area meter and that estimated by millimeter graph paper method across thirty-three plant species $(n=640)$.

attached leaf samples were also drawn on the millimeter graph paper. The area of the graph paper covered by the outline was cut and weighed. A one $\mathrm{cm}^{2}$ of the millimeter graph paper was also cut and weighed. There were six hundred forty detached leaf samples (of thirty-three plant species), and fifty attached leaf samples (five plant species). Size of the leaves varied from 3.20 to $285.06 \mathrm{~cm}$.

The two sets of estimates (leaf area meter and millimeter graph paper) were related according to $y=a+b x$, where $y$ is the leaf area estimated by leaf area meter and $x$ is the leaf area estimated by millimeter graph paper. The independent variable here was the leaf area estimated by millimeter graph paper, and dependent variable was leaf area estimated by leaf area meter (SYSTRONICS, Leaf Area Meter-211). The regression equations were calculated by using Sigmaplot (ver.11).

\section{Results and Discussion}

Relationships between leaf area of detached leaves estimated by leaf area meter (dependent variable) and that estimated by millimeter graph paper method (independent variable) for thirty-three plant species as given in Table 1 show that the two sets of estimates are strongly related with each other for each of the thirty-three species and that the nondestructive estimates by millimeter graph paper method are as good as those obtained destructively by leaf area meter method (Figure 1). For individual species, the coefficient of determination between the two sets of estimates varied between 0.933 and 0.998 and collectively across the thirtythree, the $R^{2}$ was as high as 0.999 . These relationships were also tested on attached leaf samples for five species (Table 2). Relationships were again linear and significant, $\left(R^{2}=0.996\right.$ to 0.998 , Figure 2).

Easily measured leaf parameters such as length and width, and their combinations have been used for nondestructive leaf area estimation, though the accuracy of the predictions is dependent on the variation of the leaf shape due to differential genotypes (Cristofori et al. [35], Cristofori et al. [39], Zhang and Liu [47]). The ratio of length to width is highly variable among the species due to complexity in the leaf shapes. On the other hand, the method using leaf 
TABLE 1: Regression equations and coefficients of determination $\left(R^{2}\right)$ between leaf area measured by leaf area meter $\left(y, \mathrm{~cm}^{2}\right)$ and that estimated by millimeter graph paper method $\left(x, \mathrm{~cm}^{2}\right)$ for thirty-three plant species, $(n=10$ for each species). Observations were made on detached leaves.

\begin{tabular}{|c|c|c|c|c|}
\hline S. no. & Species & Month of sampling & Regression equation & $R^{2}$ \\
\hline \multirow{3}{*}{1} & Albizia lebbeck & September & $Y=0.742 X+0.741$ & 0.933 \\
\hline & Albizia lebbeck & September & $Y=0.785 X+0.478$ & 0.859 \\
\hline & Albizia lebbeck & October & $Y=1.093 X-1.685$ & 0.986 \\
\hline \multirow{2}{*}{2} & Anacardium occidentale & August & $Y=0.986 X-1.159$ & 0.995 \\
\hline & Anacardium occidentale & September & $Y=1.000 X-2.147$ & 0.991 \\
\hline 3 & Anthocephalus cadamba & September & $Y=0.986 X-1.495$ & 0.997 \\
\hline \multirow{2}{*}{4} & Artocarpus heterophyllus & October & $Y=0.984 X-0.947$ & 0.998 \\
\hline & Artocarpus heterophyllus & October & $Y=0.972 X-0.894$ & 0.993 \\
\hline 5 & Artocarpus lakoocha & August & $Y=1.085 X-2.753$ & 0.977 \\
\hline \multirow{2}{*}{6} & Bombax ceiba & August & $Y=0.955 X-0.649$ & 0.993 \\
\hline & Bombax ceiba & October & $Y=0.961 X-0.736$ & 0.996 \\
\hline 7 & Buchanania lanzan & August & $Y=0.975 X-0.012$ & 0.998 \\
\hline \multirow{2}{*}{8} & Butea monosperma & August & $Y=0.836 X-0.632$ & 0.953 \\
\hline & Butea monosperma & October & $Y=0.985 X-0.952$ & 0.998 \\
\hline \multirow{2}{*}{9} & Cassia fistula & August & $Y=0.942 X-0.321$ & 0.992 \\
\hline & Cassia fistula & September & $Y=0.988 X-1.510$ & 0.997 \\
\hline \multirow{2}{*}{10} & Crescentia cujete & September & $Y=0.976 X-0.426$ & 0.998 \\
\hline & Crescentia cujete & August & $Y=0.983 X-1.458$ & 0.995 \\
\hline 11 & Diospyros melanoxylon & October & $Y=0.973 X-0.954$ & 0.997 \\
\hline 12 & Eucalyptus globulus & September & $Y=0.948 X-0.330$ & 0.991 \\
\hline 13 & Ficus benghalensis & September & $Y=0.971 X-0.763$ & 0.997 \\
\hline 14 & Ficus carica & August & $Y=0.986 X-1.170$ & 0.994 \\
\hline \multirow{3}{*}{15} & Ficus religiosa & September & $Y=1.000 X-1.879$ & 0.997 \\
\hline & Ficus religiosa & October & $Y=0.991 X-2.296$ & 0.997 \\
\hline & Ficus religiosa & October & $Y=0.995 X-1.863$ & 0.998 \\
\hline 16 & Hibiscus rosa-sinensis & October & $Y=0.970 X-0.813$ & 0.995 \\
\hline \multirow{2}{*}{17} & Holoptelea integrifolia & August & $Y=0.982 X-1.367$ & 0.998 \\
\hline & Holoptelea integrifolia & October & $Y=0.962 X-0.478$ & 0.998 \\
\hline \multirow{3}{*}{18} & Litchi chinensis & August & $Y=0.989 X-2.009$ & 0.995 \\
\hline & Litchi chinensis & August & $Y=0.970 X-0.816$ & 0.996 \\
\hline & Litchi chinensis & October & $Y=0.964 X-0.862$ & 0.993 \\
\hline \multirow{2}{*}{19} & Madhuca indica & August & $Y=0.991 X-1.925$ & 0.995 \\
\hline & Madhuca indica & October & $Y=0.990 X-1.933$ & 0.998 \\
\hline \multirow{3}{*}{20} & Mangifera indica & August & $Y=0.997 X-1.801$ & 0.998 \\
\hline & Mangifera indica & October & $Y=0.983 X-1.241$ & 0.996 \\
\hline & Mangifera indica & October & $Y=0.996 X-1.177$ & 0.998 \\
\hline \multirow{2}{*}{21} & Melia azadirachta & August & $Y=1.007 X-1.338$ & 0.977 \\
\hline & Melia azadirachta & September & $Y=1.023 X-1.122$ & 0.969 \\
\hline \multirow{2}{*}{22} & Morus alba & August & $Y=0.973 X-0.735$ & 0.996 \\
\hline & Morus alba & September & $Y=0.978 X-0.534$ & 0.998 \\
\hline \multirow{3}{*}{23} & Polyalthia longifolia & August & $Y=0.966 X-0.644$ & 0.998 \\
\hline & Polyalthia longifolia & August & $Y=0.967 X-0.887$ & 0.998 \\
\hline & Polyalthia longifolia & September & $Y=1.014 X-2.366$ & 0.993 \\
\hline 24 & Populus alba & August & $Y=0.956 X-0.708$ & 0.993 \\
\hline \multirow{2}{*}{25} & Psidium guajava & September & $Y=0.969 X-0.600$ & 0.994 \\
\hline & Psidium guajava & September & $Y=0.959 X-0.634$ & 0.997 \\
\hline
\end{tabular}


Table 1: Continued.

\begin{tabular}{|c|c|c|c|c|}
\hline S. no. & Species & Month of sampling & Regression equation & $R^{2}$ \\
\hline \multirow{5}{*}{26} & Sapindus emarginatus & August & $Y=0.98 X-1.097$ & 0.997 \\
\hline & Sapindus emarginatus & September & $Y=0.967 X-0.787$ & 0.989 \\
\hline & Sapindus emarginatus & September & $Y=0.976 X-1.025$ & 0.997 \\
\hline & Sapindus emarginatus & September & $Y=0.997 X-1.474$ & 0.998 \\
\hline & Sapindus emarginatus & August & $Y=0.987 X-1.202$ & 0.992 \\
\hline \multirow{2}{*}{27} & Shorea robusta & August & $Y=0.97 X-0.735$ & 0.997 \\
\hline & Shorea robusta & October & $Y=0.997 X-2.629$ & 0.998 \\
\hline \multirow{2}{*}{28} & Sporadic pinata & August & $Y=0.959 X-0.475$ & 0.995 \\
\hline & Sporadic pinata & October & $Y=1.024 X-3.014$ & 0.996 \\
\hline \multirow{2}{*}{29} & Sterculia colorata & October & $Y=1.011 X-3.651$ & 0.998 \\
\hline & Sterculia colorata & August & $Y=1.002 X-2.912$ & 0.998 \\
\hline \multirow{3}{*}{30} & Syzygium jambolanum & September & $Y=0.964 X-0.065$ & 0.996 \\
\hline & Syzygium jambolanum & September & $Y=1.002 X-1.887$ & 0.997 \\
\hline & Syzygium jambolanum & October & $Y=0.976 X-0.709$ & 0.998 \\
\hline 31 & Tectona grandis & September & $Y=0.996 X-2.180$ & 0.998 \\
\hline 32 & Terminalia chebula & October & $Y=0.979 X-0.767$ & 0.998 \\
\hline \multirow{2}{*}{33} & Terminalia tomentosa & August & $Y=0.977 X-0.676$ & 0.997 \\
\hline & Terminalia tomentosa & October & $Y=0.974 X-1.089$ & 0.992 \\
\hline
\end{tabular}

All $R^{2}$ values are significant at $P<0.0001$.

TABLE 2: Regression equations and coefficients of determination $\left(R^{2}\right)$ between leaf area measured by leaf area meter $\left(y, \mathrm{~cm}^{2}\right)$ and that estimated by millimeter graph paper method $\left(x, \mathrm{~cm}^{2}\right)$ for five plant species, $(n=10$ for each species). Observations were made on attached leaves.

\begin{tabular}{lcclr}
\hline S. no. & Species & Month of sampling & \multicolumn{1}{c}{ Regression equation } \\
\hline 1 & Crescentia cujete & August & $Y=0.953 X-1.247$ & $R^{2}$ \\
2 & Hibiscus rosa-sinensis & October & $Y=0.984 X-2.436$ & 0.996 \\
3 & Morus alba & September & $Y=0.979 X-1.580$ & 0.998 \\
4 & Populus alba & August & $Y=0.967 X-1.537$ & 0.998 \\
5 & Psidium guajava & September & $Y=1.030 X-2.483$ & 0.997 \\
\hline
\end{tabular}

All $R^{2}$ values are significant at $P<0.0001$.

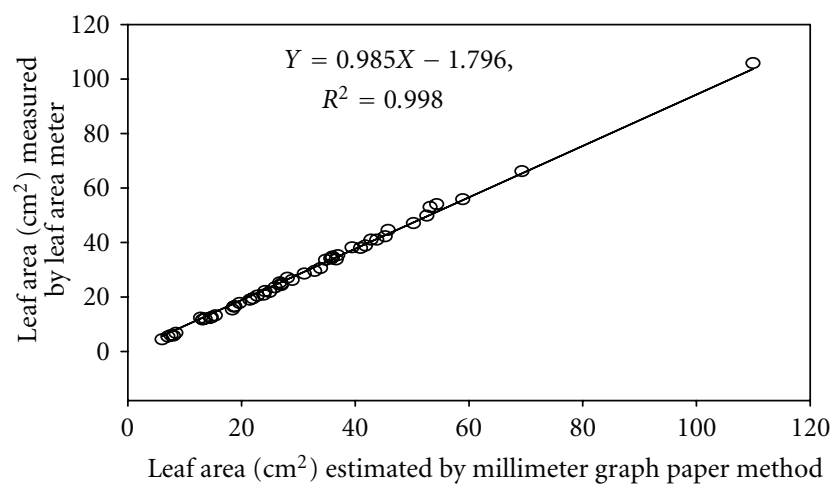

Figure 2: Relationship between leaf area of attached leaves measured by leaf area meter and that estimated by millimeter graph paper method across five plant species $(n=50)$.

outline on millimeter graph paper can be successfully used to estimate leaf area across variety of species. Some important factors which affect the accuracy of the millimeter graph paper method are the lack of proper spread of leaf over millimeter graph paper, absence of accurate drawing of leaf margins, lack of even cutting of the drawn outline, and lack of precision in weighing. The errors originating from the leaves not being perfectly flat, overlying leaflets, and similar factors are common to both the millimeter graph paper and leaf area meter. The millimeter graph paper method is faster and can be applied to attached leaves (nondestructive) and anywhere as in forest or agricultural field.

\section{Conclusion}

The millimeter graph paper method described in this paper was used to estimate individual leaf area of thirty-three woody species. The estimates had significant linear relationships with the estimates obtained by using sophisticated leaf area meter. The millimeter graph paper method can estimate precisely and in large quantities leaf area of plants in many experimental comparisons without the use of costly instruments. 


\section{Acknowledgment}

The authors thank the Ministry of Environment and Forests, Government of India, for providing financial assistance.

\section{References}

[1] F. F. Blanco and M. V. Folegatti, "Estimation of leaf area for greenhouse cucumber by linear measurements under salinity and grafting," Agricultural Science, vol. 62, no. 4, pp. 305-309, 2005.

[2] Z. Sestak, J. Catsky, and P. G. Jarvis, Plant Photosynthesis Production, Mannual of Methods, Junk Publishers, The Hague, The Netherlands, 1971.

[3] L. L. Tieszen, "Biomass accumulation and primary production," in Techniques in Bio-Productivity \& Photosynthesis, J. Coombs and D. O. Hall, Eds., pp. 16-19, Pergamon Press, Oxford, UK, 1982.

[4] J. K. A. Bleasdale, Plant Physiology in Relation to Horticulture, Macmillan Press, London, UK, 2nd edition, 1984.

[5] J. L. Harper, Population Biology of Plants, Academic Press, Oxford, UK, 1977.

[6] N. N. Mohsenin, Physical Properties of Plant and Animal Materials, Gordon and Breach Science Publishers, New York, NY, USA, 1986.

[7] R. E. Smart, "Photosynthesis by grapevine canopies," Journal of Applied Ecology, vol. 11, no. 3, pp. 997-1006, 1974.

[8] L. E. Williams, "Growth of "Thompson Seedless" grapevines: I. Leaf area development and dry weight distribution," Journal of American Society and Horticultural Science, vol. 112, no. 2, pp. 325-330, 1987.

[9] J. K. Marshall, "Methods for leaf area measurement of large and small leaf samples," Photosynthetica, vol. 2, pp. 41-47, 1968.

[10] U. Brodny, R. R. Nelson, and L. V. Gregory, "The residual and interactive expression of "defeated" wheat stem rust resistance genes," Phytopathology, vol. 76, no. 5, pp. 546-549, 1986.

[11] C. Daughtry, "Direct measurements of canopy structure," Remote Sensing Reviews, vol. 5, no. 1, pp. 45-60, 1990.

[12] E. Nyakwende, C. J. Paull, and J. G. Atherton, "Nondestructive determination of leaf area in tomato plants using image processing," Journal of Horticultural Science, vol. 72, no. 2, pp. 255-262, 1997.

[13] C. Bignami and F. Rossini, "Image analysis estimation of leaf area index and plant size of young hazelnut plants," Journal of Horticultural Science and Biotechnology, vol. 71, no. 1, pp. 113-121, 1996.

[14] F. J. Montero, J. A. De Juan, A. Cuesta, and A. Brasa, "Nondestructive methods to estimate leaf area in Vitis vinifera L," HortScience, vol. 35, no. 4, pp. 696-698, 2000.

[15] L. Williams and T. E. Martinson III, "Nondestructive leaf area estimation of "Niagara" and "Dechaunac" grapevines," Scientia Horticulturae, vol. 98, no. 4, pp. 493-498, 2003.

[16] S. Uzun and H. Celik, "Leaf area prediction models for different horticultural plants," Tropical Journal and Agricultural Forest, vol. 23, no. 6, pp. 645-650, 1999.

[17] A. Ranjbar and P. Damme, "Estimation of leaf area by nondestructivemethods in three ranian pistachio species (Pistacia mutica subsp. Cabulica, Pistacia khinjuk subsp. blonda and Pistacia khinjuk subsp. Populifolia)," MededelingenFaculteit Landbouwkundige en Toegepaste BiologischeWtenschappen Universiteit Gent, Belgium, vol. 64, no. 2, pp. 49-56, 1999.
[18] H. Demirsoy and L. Demirsoy, "A validated leaf area prediction model for some cherry cultivars in Turke," Pakistan Journal of Biological Sciences, vol. 35, no. 2, pp. 361-367, 2003.

[19] H. Demirsoy, L. Demirsoy, S. Uzun, and B. Ersoy, "Nondestructive leaf area estimation in peach," European Journal of Horticultural Science, vol. 69, no. 4, pp. 144-146, 2004.

[20] U. Serdar and H. Demirsoy, "Non-destructive leaf area estimation in chestnut," Scientia Horticulturae, vol. 108, no. 2, pp. 227-230, 2006.

[21] L. Manivel and R. J. Weaver, "Biometric correlations between leafarea and length measurements of "Grenache" grape leaves," Hort Science, vol. 9, pp. 27-28, 1974.

[22] G. R. Sepulveda and W. M. Kliewer, "Estimation of leaf area of two grapevine cultivars (Vitis vinifera L.) using laminae linear measurements and fresh weight," American Journal of Enology and Viticulture, vol. 34, no. 4, pp. 221-226, 1983.

[23] J. Kvet and J. K. Marshall, "Assessment of leaf area and other assimilating plant surfaces," in Plant Photosynthetic Production, Z. Sestak, J. Catsky, and P. G. Jarvis, Eds., Manual of Methods, pp. 517-555, Junk Publishers, The Hague, The Netherlands, 1971.

[24] H. Y. Lu, C. T. Lu, M. L. Wei, and L. F. Chan, "Comparison of different models for nondestructive leaf area estimation in taro," Agronomy Journal, vol. 96, no. 2, pp. 448-453, 2004.

[25] D. W. Stewart and L. M. Dwyer, "Mathematical characterization of leaf shape and area of maize hybrids," Crop Science, vol. 39, no. 2, pp. 422-427, 1999.

[26] M. Bhatt and S. V. Chanda, "Prediction of leaf area in Phaseolus vulgaris by non-destructive method," Bulgarian Journal of Plant Physiology, vol. 29, no. 2, pp. 96-100, 2003.

[27] H. Gamper, "Nondestructive estimates of leaf area in white clover using predictive formulae: the contribution of genotype identity to trifoliate leaf area," Crop Science, vol. 45, no. 6, pp. 2552-2556, 2005

[28] J. T. Tsialtas and N. Maslaris, "Leaf area estimation in a sugar beet cultivar by linear models," Photosynthetica, vol. 43, no. 3, pp. 477-479, 2005.

[29] J. T. Tsialtas and N. Maslaris, "Leaf area prediction model for sugar beet (Beta vulgaris L.) cultivars," Photosynthetica, vol. 46, no. 2, pp. 291-293, 2008.

[30] Y. Rouphael, G. Colla, S. Fanasca, and F. Karam, "Leaf area estimation of sunflower leaves from simple linear measurements," Photosynthetica, vol. 45, no. 2, pp. 306-308, 2007.

[31] A. Salerno, C. M. Rivera, Y. Rouphael et al., "Leaf area estimation of radish from simple linear measurements," Advances in Horticultural Science, vol. 19, no. 4, pp. 213-215, 2005.

[32] Y. Rouphael, C. M. Rivera, M. Cardarelli, S. Fanasca, and G. Colla, "Leaf area estimation from linear measurements in zucchini plants of different ages," Journal of Horticultural Science and Biotechnology, vol. 81, no. 2, pp. 238-241, 2006.

[33] H. Demirsoy, L. Demirsoy, and A. Öztürk, "Improved model for the non-destructive estimation of strawberry leaf area," Fruits, vol. 60, no. 1, pp. 69-73, 2005.

[34] E. Mendoza-de Gyves, Y. Rouphael, V. Cristofori, and F. R. Mira, "A non-destructive, simple and accurate model for estimating the individual leaf area of kiwi (Actinidia deliciosa)," Fruits, vol. 62, no. 3, pp. 171-176, 2007.

[35] V. Cristofori, Y. Rouphael, E. Mendoza-de Gyves, and C. Bignami, "A simple model for estimating leaf area of hazelnut from linear measurements," Scientia Horticulturae, vol. 113, no. 2, pp. 221-225, 2007.

[36] C. M. Rivera, Y. Rouphael, M. Cardarelli, and G. Colla, "A simple and accurate equation for estimating individual leaf 
area of eggplant from linear measurements," European Journal of Horticultural Science, vol. 72, no. 5, pp. 228-230, 2007.

[37] E. Peksen, "Non-destructive leaf area estimation model for faba bean (Vicia faba L.)," Scientia Horticulturae, vol. 113, no. 4, pp. 322-328, 2007.

[38] K. Ramesh, N. Ramawat, and V. Singh, "Leaf area distribution pattern and non-destructive estimation methods of leaf area for Stevia rebaudiana (Bert) Bertoni," Asian Journal of Plant Sciences, vol. 6, no. 7, pp. 1037-1043, 2007.

[39] V. Cristofori, C. Fallovo, E. Mendoza-de Gyves, C. M. Rivera, C. Bignami, and Y. Rouphael, "Non-destructive, analogue model for leaf area estimation in persimmon (Diospyros kaki L.f.) based on leaf length and width measurement," European Journal of Horticultural Science, vol. 73, no. 5, pp. 216-221, 2008.

[40] E. Mendoza-de Gyves, V. Cristofori, C. Fallovo, Y. Rouphael, and C. Bignami, "Accurate and rapid technique for leaf area measurement in medlar (Mespilus germanica L.)," Advances in Horticultural Science, vol. 22, no. 3, pp. 223-226, 2008.

[41] C. Fallovo, V. Cristofori, E. Mendoza-de Gyves et al., "Leaf area estimation model for small fruits from linear measurements," American Society for Horticultural Science, vol. 43, no. 7, pp. 2263-2267, 2008.

[42] G. Fascella, P. Maggiore, G. V. Zizzo, G. Colla, and Y. Rouphael, "A simple and low-cost method for leaf area measurement in Euphorbia x lomi Thai hybrids," Advances in Horticultural Science, vol. 23, no. 1, pp. 57-60, 2009.

[43] R. Kumar, "Calibration and validation of regression model for non-destructive leaf area estimation of saffron (Crocus sativus L.)," Scientia Horticulturae, vol. 122, no. 1, pp. 142-145, 2009.

[44] K. Kandiannan, U. Parthasarathy, K. S. Krishnamurthy, C. K. Thankamani, and V. Srinivasan, "Modeling individual leaf area of ginger (Zingiber officinale Roscoe) using leaf length and width," Scientia Horticulturae, vol. 120, no. 4, pp. 532-537, 2009.

[45] Y. Rouphael, A. H. Mouneimne, A. Ismail, E. Mendoza-de Gyves, C. M. Rivera, and G. Colla, "Modeling individual leaf area of rose (Rosa hybrida L.) based on leaf length and width measurement," Photosynthetica, vol. 48, no. 1, pp. 9-15, 2010.

[46] Y. Rouphael, A. H. Mouneimne, C. M. Rivera, M. Cardarelli, A. Marucci, and G. Colla, "Allometric models for nondestructive leaf area estimation in grafted and ungrafted watermelon (Citrullus lanatus Thunb)," Journal of Food, Agriculture and Environment, vol. 8, no. 1, pp. 161-165, 2010.

[47] L. Zhang and X. S. Liu, "Non-destructive leaf-area estimation for Bergenia purpurascens across timberline ecotone, southeast Tibet," Annales Botanici Fennici, vol. 47, no. 5, pp. 346-352, 2010. 

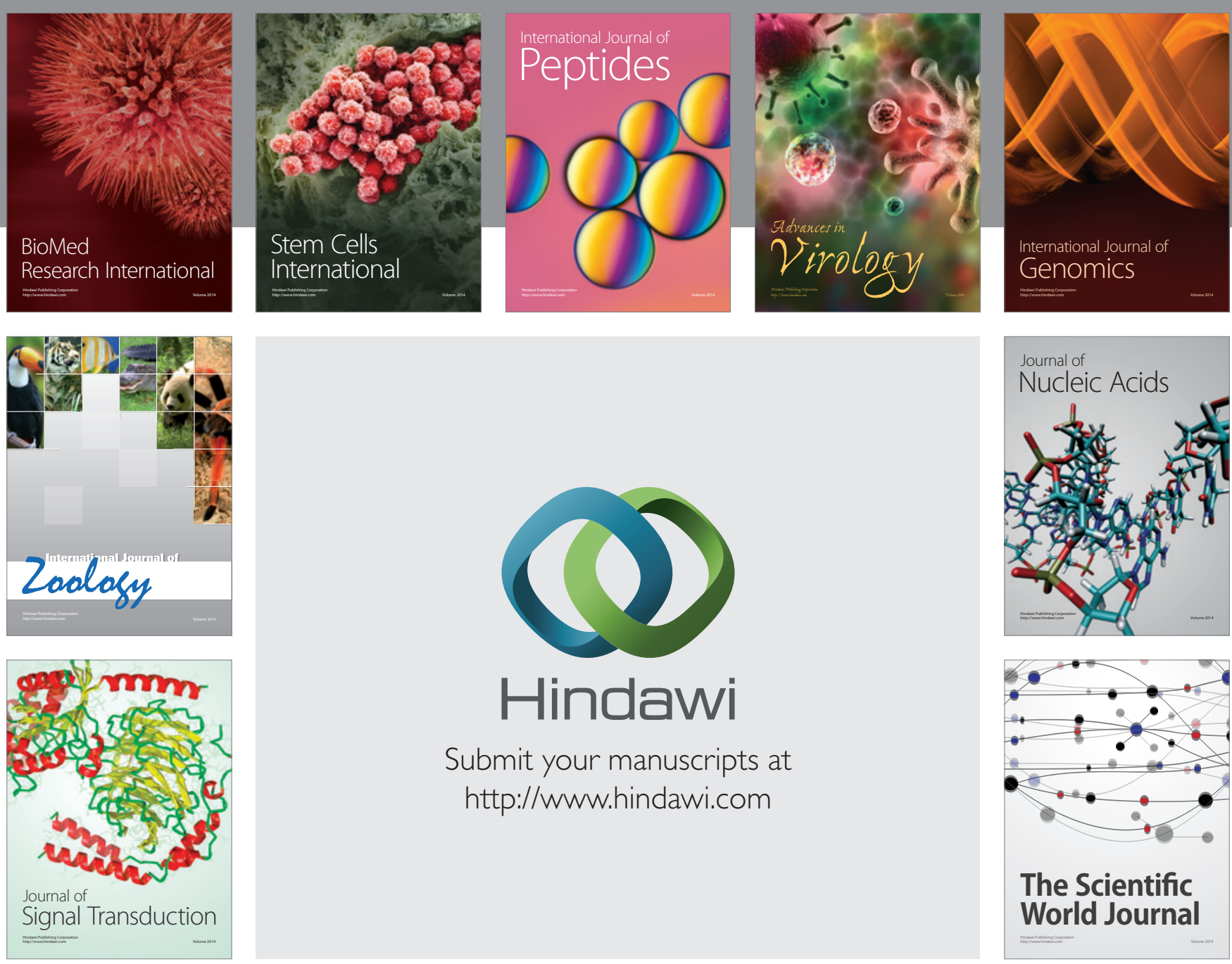

Submit your manuscripts at

http://www.hindawi.com
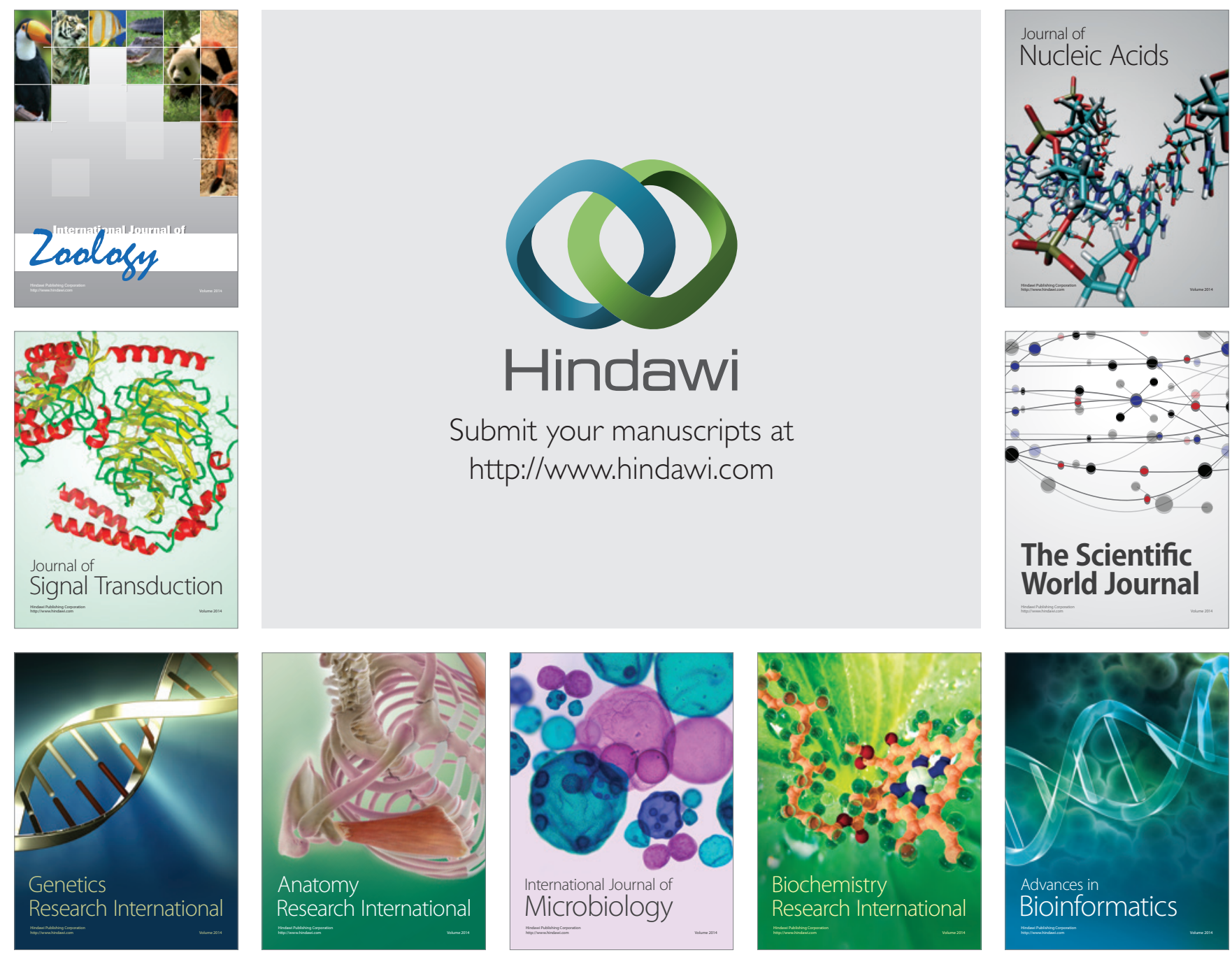

The Scientific World Journal
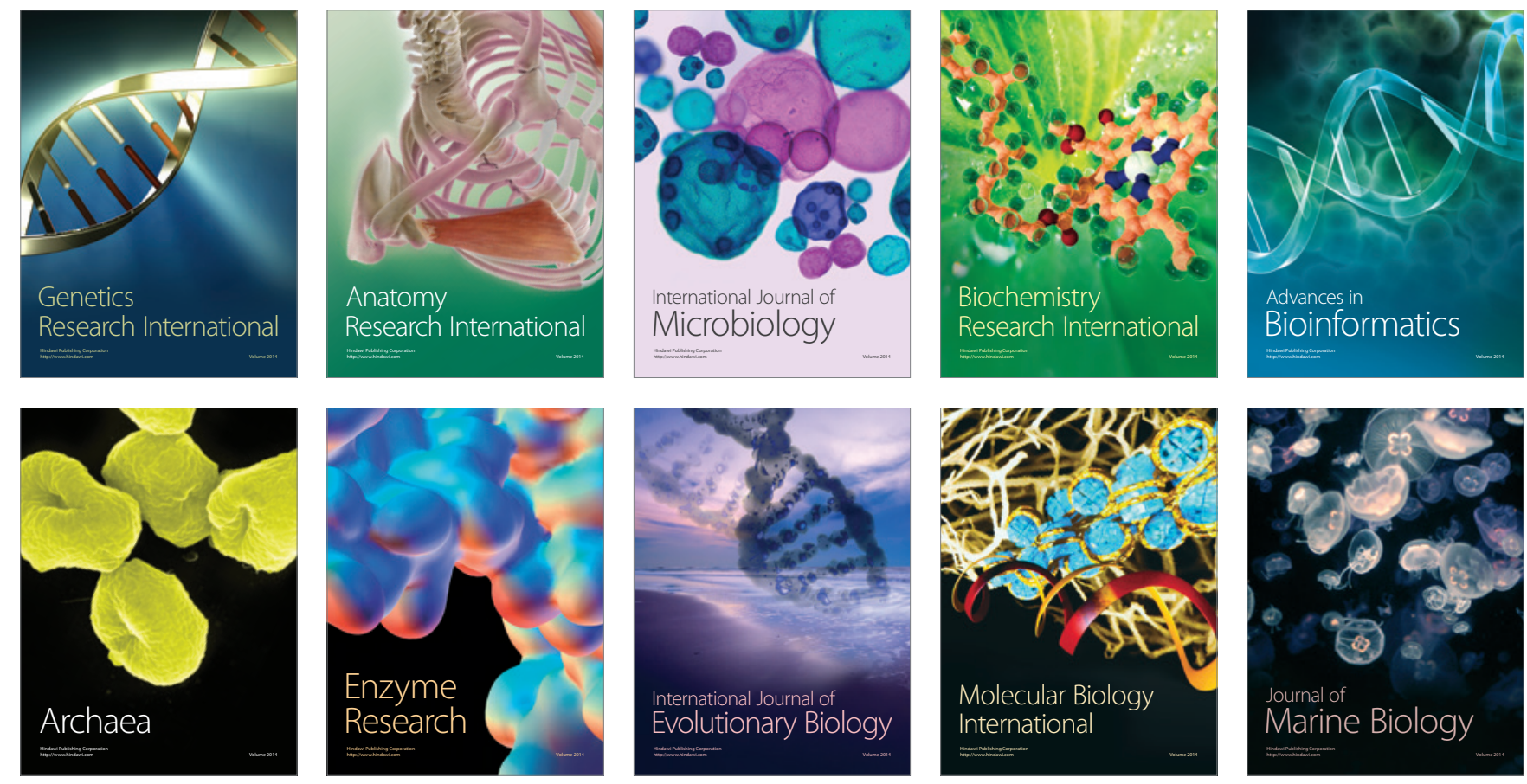